\title{
WHAT SOURCES OF FINANCE CONSTRAIN VIETNAMESE LISTED FIRMS?
}

\author{
LE LONG HAU \\ Cantho University, Vietnam - llhau@ @ctu.edu.vn
}

(Received: March 14, 2017; Revised: March 24, 2017; Accepted: April 10, 2017)

\begin{abstract}
This study is to investigate the sources of finance imposing the constraints on Vietnamese listed firms, after the introduction and rapid growth of the equity markets and the privatization wave that started since 1992. Using accounting data of listed firms on the Vietnamese stock markets, we find that listed firms are financially constrained with respect to both external funding sources, equity and long-term debt finance. Particularly, state-owned firms do exhibit higher sensitivity coefficients of equity than private firms, albeit with a non-statistically significant difference. For bank loan financing, we notice that large (HOSE listed) state-owned firms show a sensitivity that is three times the sensitivity of the private firms. The smaller HNX listed firms, however, show the reverse result, the private firms have a sensitivity coefficient that is twice as large as the one for the state-owned firms.
\end{abstract}

Keywords: Vietnam; finance constraints; state-dominated.

\section{Introduction}

Information asymmetries make external finance more costly than internal finance. If financing becomes too costly, firms face difficulties in raising enough capital in order to realise their investment ambitions. These firms are said to be finance constrained (Fazzari et al., 1988). In order to relax finance constraints on firms, a well-functioning financial system is needed and must be established. Following other developing countries, in 2000, Vietnam decided to provide an extra semi-direct financing channel through the stock market besides the existing direct financing through financial institutions (29 commercial banks and many non-bank financial institutions). However, the growth of equity markets is potentially driven by speculative motives, and financing channels in developing countries often suffer from poor accounting practices, price manipulation, and so on. As a consequence, the fact that these funding channels are quickly increasing in scale does not necessarily mean that they are sophisticated and/or driven by real economic growth (Shirai, 2004). In fact, Le et al., (2016) show that listed Vietnamese state-dominated firms face finance constraints after the introduction and rapid growth of the equity markets and the privatization wave that started in the nineties. Especially, large statedominated firms are documented to be significantly more financially constrained. Following Le et al., (2016), this paper further aims to identify what sources of finance constrain on them.

The remainder of the paper is structured as follows. Section 2 reviews the existing literature, while section 3 presents the methodology used. Section 4 describes the data and their descriptive statistics. Empirical results are discussed in section 5 followed by a conclusion.

\section{Literature review}

Since the seminal study of Fazzari et al. (1988), the common approach for testing the presence of finance constraints is to split the sample of firms into a 'high-information cost' group and a 'low-information cost' group (Ganesh Kumar et al., 2002) using a priori chosen information cost proxy. Firms that incur high information costs are expected to 
experience more finance constraints than those with low information costs. Fazzari et al. (1988) divide the sample into two groups depending on their payout rates. For both groups, they then regress the firms' investment on the firms' cash flow and a number of control variables. Under the assumption of a perfect capital market, one would not expect a statistically significant difference in the coefficient of the cash flow variable for the two groups. However, their findings show that the cash flow coefficient is larger for the group of firms with low payout rates, which indicates a higher level of finance constraint for this group. Empirical studies differ with respect to the choice of the a priori proxy used to separate the two groups. Both firm characteristics, such as size, growth objective (R\&D objective) (Bhaduri, 2005, Ghosh, 2006, Harris et al., 1994, Guncavdi et al., 1998, Laeven, 2002, Hermes and Lensink, 1998, Forbes, 2007), and ownership structure, as well as government policy oriented criteria were advanced (Poncet et al., 2010, Guariglia et al., 2011, Lizal and Svejnar, 2002). In Vietnam, Le et al., (2016) use the ownership structure - state-dominated firm or private firm - as a priori criterion to classify firms into a high (that is, state-dominated firms) and a low (that is, private firms) degree of the financially constrained group, in which the first group of firms is found to be more financially constrained than the latter. The list of empirical studies is not exhausted.

\section{Methodology}

\subsection{Empirical specifications}

Following Summers (1981) and Hayashi (1982), Fazzari et al. (1988) develop an empirical model to test for financing constraints. Taking all practical issues into account, several studies adapt the model to test for financing constraints in developing countries as follows (for example, Athey and Laumas (1994), Harris et al. (1994), Ganesh Kumar et al. (2001), (2002) and Carreira and Silva (2010)). The adjusted specification reads

$$
\begin{aligned}
& \frac{I_{i_{s} t}}{K_{i_{s}, t-1}}=\gamma_{1} \frac{\Delta S_{i_{s} t}}{K_{i_{s} t-1}}+\gamma_{2} \frac{\Delta E F_{i_{s} t}}{K_{i_{s} t-1}}+v_{i_{s} t} \\
& \quad \begin{array}{l}
\text { and, } \\
v_{\mathrm{i}_{s} \mathrm{t}}
\end{array}=\lambda_{i}+\eta_{t}+\varepsilon_{i_{s} t}
\end{aligned}
$$

where $I_{i, t}$ denotes the investments in plant and equipment for firm $i$ during period $t ; K_{i, t}$ symbolises the beginning-of-period capital stock for firm $i$ at period $t ; \Delta S_{i, t}$ denotes changes in sales over period $t ; \triangle E F$ denotes the new external sources of finance such as loans, bonds and equity finance; $v_{i, t}$ indicates a composite error term which consists of the time invariant firm-specific effect, $\lambda_{i}$, the common time effect, $\eta_{t}$, and $u_{i, t}$ is the error terms.

The coefficient of $\Delta S\left(\widehat{\gamma}_{1}\right)$ is expected to be positive and significant according to the accelerator model. A significant positive and greater coefficient of $\Delta E F\left(\widehat{\gamma_{2}}\right)$ for the highinformation cost group of firms than for the low-information cost group can be considered as sufficient evidence to support the hypothesis that the extent to which the firm's investment is sensitive to external funds varies across firm's types.

In order to identify the source(s) of funds imposing the constraints on firms, external fund $(\triangle E F)$ in the investment specification (1) is decomposed into its constituents, that is, fresh equity finance and new long-term debts, to estimate the sensitivity of each source to the firm's investment. This leads to empirical specification (2)

$$
\begin{aligned}
& \frac{I_{i, t}}{K_{i, t-1}}=\varphi_{1} \frac{\Delta S_{i, t}}{K_{i, t-1}}+\varphi_{2} \frac{\Delta E Q U I T Y_{i, t}}{K_{i, t-1}}+\varphi_{3} \frac{\Delta L T_{-} L O A N_{i, t}}{K_{i, t-1}}+v_{i, t} \\
& \quad \text { and, } \\
& \quad v_{i, t}=\lambda_{i}+\eta_{t}+\varepsilon_{i, t}
\end{aligned}
$$

where all variables are mentioned previously, except $\triangle E Q U I T Y$ denotes firm's fresh equity finance and $\triangle L T \_L O A N$ represents the new long-term debts of the firm.

The size of coefficients of $\triangle E Q U I T Y$ $\left(\widehat{\varphi_{2}}\right)$ and $\triangle L T \_L O A N\left(\widehat{\varphi_{3}}\right)$ indicates the 
extent to which firm's investment is sensitive to each source of funds. In other words, these coefficients reveal the degree of finance constraints for firms across external providers of funds. Taking the size of estimated coefficients into account, the role of each source of funds in comparison to the others can be judged. For example, if $\widehat{\varphi_{2}}$ is greater than $\widehat{\varphi_{3}}$, it can be concluded that the stock market imposes more constraints on firms than commercial banks.

Using the same approach with Le et al., (2016), the ownership structure - statedominated firm or private firm - is utilized as a priori criterion to classify firms into a high high-information cost group (i.e, statedominated firms) and a low -information cost group (i.e., private firms) in this paper. While Le et al., (2016) estimate equation (1) and find that state-dominated firms are more financially constrained, this study investigates the source(s) of finance imposing the constraints on firms by testing specification (2).

\subsection{Methods}

Three estimation procedures can be applied for panel data analysis, that is, pooled Ordinary Least Squares (pooled OLS) estimation, random effect (RE) estimation or fixed effect (FE) estimation (Plasmans, 2006). However, the use of OLS models gives biased and inconsistent results if there is unobserved heterogeneity (unobserved individual-specific effects among firms). To avoid this bias, usually a FE estimator is used (Schaller, 1993, Perotti and Vesnaver, 2004). Moreover, since the data in this study cover almost all listed firms on both stock exchanges rather than a random sample drawn from a population of listed firms, the FE estimator is also a more appropriate estimator than the RE estimator (Dougherty, 2007). Consequently, we will use the FE estimator in our analysis.

\section{Data analyses}

\subsection{Data collected}

The study uses a panel of all firms that were listed on the Vietnamese stock exchanges at any time during 2006Q1 2009Q4. The panel consists of 417 firms. $^{1}$ Financials are not included in the sample because their balance sheet structure is completely different from that of industrials. Due to the lack of data availability in some periods for many firms, we use an unbalanced panel. All quarterly accounting data were obtained manually from the Ho Chi Minh City Stock Exchange (HOSE), the Hanoi Stock Exchange (HNX), and the websites of security firms and listed firms.

Following Guariglia et al. (2011), a firm is categorised as 'state-dominated firm' if the government holds more than 50 per cent of its total shares; otherwise it is assigned to the group of 'private firms'. This percentage of ownership is chosen as a cut-off point in time at the end of 2009Q4 due to the shortage of available data. ${ }^{2}$ The choice of the end 2009Q4 is not likely to affect our study severely since it is not the objective of the paper to study the effect of firms' transitions from statedominated firms to private ones. Also, the use of a time-invariant measure of stateownership can minimise the measurement errors in this variable (Guariglia et al., 2011).

\subsection{Descriptive statistics}

Table 1 presents the descriptive statistics of all our variables. We notice a wide range of investment activities: some firms disinvest, others invest significantly vis-à-vis their capital stock. With respect to the financing variables, we notice that additional equity finance accounts for a much greater proportion than financing through long-term loans. This illustrates the importance of the new stock exchanges for the Vietnamese economy. 


\section{Table 1}

Descriptive statistics

The table reports the descriptive statistics of all variables for the whole sample, the group of private firms and the group of state-owned firms. In the table, $I N V$ denotes investment of the firm; $K_{(t-1)}$ is the previousperiod capital stock of the firm; $\triangle S$ symbolizes the change in total sales; $\triangle L T_{-} L O A N$ is the new long-term debt and $\triangle E Q U I T Y$ denotes fresh equity finance of firms.

Panel A: Whole sample (\%)

\begin{tabular}{lcrrrr}
\hline Variable & Obs. & Mean & Std. & Min & Max \\
\hline$I N V / K_{(t-1)}$ & 1144 & 2.25 & 6.61 & -6.93 & 28.87 \\
$\Delta S / K_{(t-1)}$ & 1146 & 6.46 & 29.05 & -70.35 & 97.46 \\
$\Delta L T \_L O A N / K_{(t-1)}$ & 1144 & 0.47 & 2.15 & -4.11 & 7.64 \\
$\Delta E Q U I T Y / K_{(t-1)}$ & 1144 & 5.25 & 5.16 & -2.55 & 18.38 \\
\hline
\end{tabular}

Panel B: Whole sample by firms' groups (private and state-owned) (\%)

\begin{tabular}{lcrrrrrrrrr}
\hline \multicolumn{1}{c}{} & \multicolumn{4}{c}{ Private firms } & \multicolumn{5}{c}{ State-owned firms } \\
\hline \multicolumn{1}{c}{ Variable } & Obs. & Mean & Std. & Min & Max & Obs. & Mean & Std. & Min & Max \\
\hline$I N V / K_{(t-1)}$ & 689 & 2.86 & 6.72 & -6.93 & 28.87 & 455 & 1.33 & 6.32 & -6.85 & 28.35 \\
$\Delta S / K_{(t-1)}$ & 691 & 8.07 & 29.57 & -69.35 & 97.46 & 455 & 4.02 & 28.10 & -70.35 & 94.62 \\
$\Delta L T_{-} L O A N / K_{(t-1)}$ & 689 & 0.36 & 2.02 & -4.11 & 7.61 & 455 & 0.64 & 2.33 & -3.96 & 7.64 \\
$\Delta E Q U I T Y / K_{(t-1)}$ & 689 & 5.47 & 5.28 & -2.53 & 18.38 & 455 & 4.92 & 4.97 & -2.55 & 18.22 \\
\hline
\end{tabular}

Panel C: For HOSE by firms' groups (private and state-owned) (\%)

\begin{tabular}{|c|c|c|c|c|c|c|c|c|c|c|}
\hline \multirow[b]{2}{*}{ Variable } & \multicolumn{5}{|c|}{ Private firms } & \multicolumn{5}{|c|}{ State-owned firms } \\
\hline & Obs. & Mean & Std. & Min & $\operatorname{Max}$ & Obs. & Mean & Std. & Min & $\operatorname{Max}$ \\
\hline$I N V / K_{(t-1)}$ & 426 & 3.59 & 6.60 & -6.93 & 28.83 & 137 & 1.34 & 6.10 & -6.82 & 27.84 \\
\hline$\Delta S / K_{(t-1)}$ & 427 & 7.59 & 28.98 & -69.35 & 97.46 & 137 & 2.16 & 25.67 & -70.35 & 94.62 \\
\hline$\Delta L T \_L O A N / K_{(t-1)}$ & 426 & 0.48 & 2.02 & -4.02 & 7.61 & 137 & 0.60 & 2.48 & -3.60 & 7.60 \\
\hline$\Delta E Q U I T Y / K_{(t-1)}$ & 426 & 5.54 & 5.34 & -2.53 & 18.14 & 137 & 5.37 & 5.24 & -2.55 & 17.79 \\
\hline \multicolumn{11}{|c|}{ Panel D: For HNX by firms' groups (private and state-owned) (\%) } \\
\hline & \multicolumn{5}{|c|}{ Private firms } & \multicolumn{5}{|c|}{ State-owned firms } \\
\hline Variable & Obs & Mean & Std. & Min & $\operatorname{Max}$ & Obs & Mean & Std. & Min & Max \\
\hline$I N V / K_{(t-1)}$ & 263 & 1.68 & 6.77 & -6.79 & 28.87 & 318 & 1.32 & 6.42 & -6.85 & 28.35 \\
\hline$\Delta S / K_{(t-1)}$ & 264 & 8.85 & 30.54 & -57.69 & 96.32 & 318 & 4.82 & 29.08 & -65.98 & 92.52 \\
\hline$\Delta L T \_L O A N / K_{(t-1)}$ & 263 & 0.17 & 2.00 & -4.11 & 7.40 & 318 & 0.66 & 2.26 & -3.96 & 7.64 \\
\hline$\Delta E Q U I T Y / K_{(t-1)}$ & 263 & 5.35 & 5.18 & -2.49 & 18.38 & 318 & 4.73 & 4.85 & -2.38 & 18.22 \\
\hline
\end{tabular}


Panel B shows the descriptive statistics for state-dominated and private firms separately. The investment to the previousperiod capital stock ratio and the sales changes to the previous-period capital stock ratio of the private group are about two times higher than that of the state-dominated group. Descriptive statistics for HOSE and HNX are shown in Panel C and Panel D, respectively. In general, the difference between the variables of the two stock exchanges seems to be marginal.

\section{Research findings}

Table 2 presents our estimation results. The specification (2) is estimated for the whole sample, and for each stock exchange (HOSE and HNX) individually to control for the heterogeneity between the two stock exchanges such as the listing criteria differences and development degree of each exchange. ${ }^{3}$ Some important points are worth noting. First, given the very low VIF statistics (that is, from 1.03 to 1.11) for all the regressions, it can be concluded that there is no evidence of multicollinearity. Second, the Wald statistics for a groupwise heteroskedasticity diagnostic test are highly statistically significant at the one per cent level, indicating that significant heteroskedasticity across firms is present. Hence, all specifications are estimated by taking into account this heteroskedasticity, that is, using cluster-robust standard errors, clustering by the panel variable (Baum, 2006). ${ }^{4}$

All the estimated coefficients of $\left[\Delta S / K_{(t-}\right.$ 1)] are positive as predicted by the salesaccelerator model, except for the group of private firms in HNX. Nevertheless, only the coefficient for private firms listed on HOSE is statistically significant at 10 per cent.

Considering the whole sample, the estimated coefficient of $\left[\Delta E Q U I T Y / K_{(t-1)}\right]$ is positive and significant. The regression suggests that investment activities are sensitive to the access to equity funding. This result, however, is (completely) driven by the large firms listed on HOSE. For HNX, no evidence of significant sensitivities is found. We also observe that for both HOSE and HNX the estimated equity sensitivity coefficients are larger for state-owned firms as compared to private firms. Formal $t$-tests, however, show that the coefficients for the group of stateowned firms are not statistically higher than those for the group of private firms at the conventional confidence levels. Hence, our results do not permit strong statistically based conclusions for new equity financing. ${ }^{5}$

For new long-term loans, we find a somewhat opposite result. While all coefficients of [ $\left.\triangle L T_{-} L O A N / K_{(t-1)}\right]$ are found to be positive and significant for the whole sample, the overall result seems to stem from very conflicting results for the large (HOSE) and small (HNX) firms. Although the sensitivity coefficients of bank financing are all positive and large compared to the sensitivities vis-à-vis new equity, the coefficients for the HOSE listed firms are not significantly different from zero. The sensitivity coefficients of the smaller firms at HNX however are both significant at the five per cent level.

While the results for the whole sample and HOSE consistently show the pattern that stateowned firms' investments are more sensitive to the long-term loans than their private counterparts, the opposite trend is found for HNX! The smaller finance constraints imposed to the state-owned firms on HNX to loans finance are consistent with the alleged importance of personal connections and political acquaintances in credit allocation in Vietnam (Malesky and Taussig, 2009). Our results suggest that especially smaller private firms exhibit a large bank financing sensitivity. Yet, again the $t$-test statistics show that coefficients for the group of state-owned firms are not statistically larger than those for the group of private firms. ${ }^{6}$ Given these results, we can conclude that listed firms are still financially constrained to both external sources of funds, that is, equity and long-term loans. Nevertheless, there is overwhelming evidence that state-owned firms face more finance constraints to either source of external funds than private firms for the whole sample as well 
as the two stock exchanges.

Recall that the coefficient of $\left[\triangle L T \_L O A N / K_{(t-1)}\right]$ is substantially larger than that of $\left[\triangle E Q U I T Y / K_{(t-1)}\right]$ in almost all cases. These findings consistently show that firms' investments are more sensitive to long-term loans than to equity financing. We attribute these findings to the fact that listed firms still mainly rely on long-term loans to finance their investment. This indicates that the Vietnamese stock exchanges still have a role to play in the Vietnamese economy (that is, raising and channelling financial resources to listed firms).

\section{Table 2}

Estimation results of specification (2) for the whole sample, HOSE and HNX

The table reports the estimated results of specification (2) for the whole sample and for each stock exchange. In the table, $I N V$ denotes investment of the firm; $K_{(t-1)}$ is the previous-period capital stock of the firm; $\triangle S$ symbolizes the change in total sales; $\triangle E Q U I T Y$ denotes total fresh equity of firm and $\triangle L T \_L O A N$ is the total new long-term loans. $t$-statistics are robust $t$-statistics after correcting for heteroskedasticity shown in parentheses. The $F$ - statistic is the result of the $F$-test on $R^{2}$. Diagnostic test statistics such as the variance inflation factor (VIF) and the Wald test statistic for groupwise heteroskedasticity are also reported. Finally, the notations ${ }^{*},{ }^{* *}$ and ${ }^{* * *}$ denote the significance levels of $10 \%, 5 \%$ and $1 \%$, respectively.

\begin{tabular}{|c|c|c|c|c|c|c|}
\hline \multirow[b]{3}{*}{ Variable } & \multicolumn{2}{|c|}{ The whole sample } & \multicolumn{2}{|c|}{ HOSE } & \multicolumn{2}{|c|}{ HNX } \\
\hline & $\begin{array}{l}\text { State- } \\
\text { owned }\end{array}$ & Private & $\begin{array}{l}\text { State- } \\
\text { owned }\end{array}$ & Private & $\begin{array}{l}\text { State- } \\
\text { owned }\end{array}$ & Private \\
\hline & & & & & & \\
\hline \multirow[t]{2}{*}{$\Delta S / K_{(t-1)}$} & 0.0116 & 0.0081 & 0.0005 & $0.0248^{*}$ & 0.0116 & -0.0147 \\
\hline & $(0.92)$ & $(0.87)$ & $(0.02)$ & (1.94) & $(0.78)$ & $(-1.06)$ \\
\hline \multirow{2}{*}{$\Delta E Q U I T Y / K_{(t-1)}$} & $0.2077^{* *}$ & $0.1197^{*}$ & $0.3271^{* *}$ & $0.1704^{* *}$ & 0.1393 & 0.0544 \\
\hline & $(2.35)$ & (1.70) & $(2.86)$ & (2.10) & (1.14) & $(0.43)$ \\
\hline \multirow[t]{2}{*}{$\Delta L T \_L O A N / K_{(t-1)}$} & $0.3944^{* *}$ & $0.3538^{*}$ & 0.4970 & 0.1671 & $0.3638^{* *}$ & $0.6901^{* *}$ \\
\hline & $(2.73)$ & (1.96) & $(1.46)$ & $(0.82)$ & $(2.26)$ & $(2.10)$ \\
\hline \multirow[t]{2}{*}{ Constant } & 0.0001 & $0.0202^{* * *}$ & -0.0071 & $0.0238^{* * *}$ & 0.0037 & $0.0142^{* *}$ \\
\hline & $(0.01)$ & $(5.18)$ & $(-1.11)$ & $(4.90)$ & $(0.61)$ & $(2.16)$ \\
\hline Observations & 455 & 688 & 137 & 426 & 318 & 262 \\
\hline$R^{2}$ & 0.05 & 0.02 & 0.15 & 0.03 & 0.03 & 0.06 \\
\hline$F$-statistic & $4.78^{* * * *}$ & $2.95^{* *}$ & $3.93^{* *}$ & $2.74^{* *}$ & 2.04 & 1.80 \\
\hline VIF & 1.04 & 1.07 & 1.11 & 1.07 & 1.03 & 1.08 \\
\hline $\begin{array}{l}\text { Wald test statistic } \\
(p \text {-value })\end{array}$ & 0.00 & 0.00 & 0.00 & 0.00 & 0.00 & 0.00 \\
\hline
\end{tabular}

\section{Conclusions}

Empirical study by Le et al., (2016) shows that irrespective of their size and irrespective of the ownership structure (state- dominated versus private firms), Vietnamese firms' investments are sensitive to the availability of external funding, indicating that large listed state-dominated firms are more 
financially constrained than private firms. In this study, we further test the sources of finance imposing the constraints on firms.

Decomposing the total new external funding into equity finance and long-term loan finance, we confirm that listed firms are financially constrained with respect to both funding sources. We find that state-owned firms do exhibit higher sensitivity coefficients of equity than private firms, albeit with a nonstatistically significant difference. For bank loan financing, we notice that large (HOSE listed) state-owned firms show a sensitivity that is three times the sensitivity of the private firms. The smaller HNX listed firms however show the reverse result, the private firms have a sensitivity coefficient that is twice as large as the one for the state-owned firms. The evidence weakly suggests that small, stateowned firms may face less finance constraints than their private counterparts.

Our findings suggest that, for smaller firms, soft budget constraints might put the state-owned firms temporarily at an advantage but only for bank finance. Notice that, at present, the major banks in Vietnam are stateowned as well. As the pecking order story suggests, equity finance is the most costly and least preferred financing source but once state-owned firms have to tap the equity market, their politically based advantage is gone too

\section{Note:}

${ }^{1}$ Although the sample comprises of five industries, the composition of each industry in the total sample stays relatively stable over time using a $x^{2}$ test on contingency table.

2 Some main characteristics of both groups of firms using this classification criterion are worth mentioning here. The state-owned type firm group has an average percentage of state ownership of roughly $58 \%$, while in private type firm group the mean of state shares is approximately $14 \%, 11 \%$ and $17 \%$ for the whole sample, HOSE and HNX respectively. In addition, majority of state-owned type firms has the state ownership in the range from $50 \%$ to $70 \%$, while most of private type firms has the state shares of $0 \%-20 \%$. Since the difference in the average percentage of state ownership between the two firm group is fairly large, our conclusions might not seem to be severely biased.

${ }^{3}$ This classification criteria up to a large extent can also help to control for firm size measured by the firm total assets. Using a simple $t$-test, we find that the average size of HOSE-listed firms is statistically significantly greater than that of HNX-listed firms.

${ }^{4}$ We would like to show our gratefulness to C.F. Baum for suggesting the Stata command to take account of this issue.

${ }^{5}$ We perform the following hypothesis test on the relevant coefficients: $\mathrm{H}_{\mathrm{o}}$ : coeff. of $\left[\Delta E Q U I T Y / K_{(t-1)}\right]_{(\text {state-owned firms) }}$ $\leq$ coeff. of $\left[\triangle E Q U I T Y / K_{(t-1)}\right]_{(\text {private firms) }}$ v.s $\mathrm{H}_{\mathrm{a}}$ : coeff. of $\left[\Delta E Q U I T Y / K_{(t-1)}\right]_{(\text {state-owned firms })}>$ coeff. of $\left[\Delta E Q U I T Y / K_{(t-1)}\right.$ ]$_{\text {(private firms) }}$ for the whole sample, HOSE and HNX; the $p$-values of the test are $0.21,0.13$ and 0.31 , respectively.

${ }^{6}$ We perform the following hypothesis test on the relevant coefficients: $\mathrm{H}_{\mathrm{o}}$ : coeff. of $\left[\Delta L T \_L O A N / K_{(t-1)}\right]_{(\text {state-owned }}$ firms) $\leq$ coeff. of $\left[\Delta L T_{-} L O A N / K_{(t-1)} / K_{(t-1)}\right]_{\text {(private firms) }}$ v.s $\mathrm{H}_{\mathrm{a}}$ : coeff. of $\left[\Delta L T_{-} L O A N / K_{(t-1)} / K_{(t-1)}\right]_{\text {(state-owned firms) }}>$ coeff. of $\left[\Delta L T \_L O A N / K_{(t-1)} / K_{(t-1)}\right]_{(\text {private firms) }}$ for the whole sample, HOSE and HNX; the $p$-values of the test are $0.43,0.20$ and $0.8 \overline{1}$, respectively.

\section{References}

Abel, A. B. \& Blanchard, O. J. (1987). The present value of profits and cyclical movements in investment. National Bureau of Economic Research Cambridge, Mass., USA.

Athey, M. J. \& Laumas, P. S. (1994). Internal funds and corporate investment in India. Journal of Development Economics, 45, 287-303.

Audretsch, D. B. \& Elston, J. A. (2002). Does firm size matter? Evidence on the impact of liquidity constraints on firm investment behavior in Germany. International Journal of Industrial Organization, 20, 1-17.

Baum, C. F. (2006). An introduction to modern econometrics using Stata, Stata Corp.

Becchetti, L. \& Trovato, G. (2002). The determinants of growth for small and medium sized firms. The role of the availability of external finance. Small Business Economics, 19, 291-306. 
Beck, N. \& Katz, J. N. (1995). What to do (and not to do) with time-series cross-section data. American political science review, 634-647.

Blalock, G., Gertler, P. J. \& Levine, D. I. (2008). Financial constraints on investment in an emerging market crisis. Journal of Monetary Economics, 55, 568-591.

Bond, S., Klemm, A., Newton-Smith, R., Syed, M. \& Vlieghe, G. (2004). The roles of expected profitability, Tobin's Q and cash flow in econometric models of company investment. Bank of England Working Paper, 222.

Bougheas, S., Goerg, H. \& Strobl, E. (2003). Is R \& D financially constrained? Theory and evidence from Irish manufacturing. Review of Industrial Organization, 22, 159-174.

Carreira, C. \& Silva, F. (2010). No deep pockets: some stylized facts empirical results on firms' financial constraints. Journal of Economic Surveys, 24, 731-753.

Cleary, S. (1999). The relationship between firm investment and financial status. The Journal of Finance, 54, 673-692.

Colombo, E. \& Stanca, L. (2006). Investment decisions and the soft budget constraint. Economics of Transition, 14, 171-198.

Davidson, R. \& Mackinnon, J. G. (1993). Estimation and inference in econometrics. OUP Catalogue.

Devereux, M. \& Schiantarelli, F. (1990). Investment, financial factors, and cash flow: evidence from UK panel data. University of Chicago Press, 1990.

Dougherty, C. (2007). Introduction to econometrics, Oxford University Press, USA.

Driscoll, J. C. \& Kraay, A. C. (1998). Consistent covariance matrix estimation with spatially dependent panel data. Review of Economics and Statistics, 80, 549-560.

Egeln, J., Licht, G. \& Steil, F. (1997). Firm foundations and the role of financing constraints. Small Business Economics, 9, 137-150.

Fazzari, S., Hubbard, R. G. \& Petersen, B. C. (1988). Financing constraints and corporate investment. NBER working paper, 2387.

Ganesh Kumar, A., Sen, K. \& Vaidya, R. (2001). Outward orientation, investment and finance constraints: A study of indian firms. Journal of Development Studies, 37, 133-149.

Ganesh Kumar, A., Sen, K. \& Vaidya, R. R. (2002). Does the source of financing matter? financial markets, financial intermediaries and investment in India. Journal of International Development, 14, 211-228.

Goergen, M. \& Renneboog, L. (2001). Investment policy, internal financing and ownership concentration in the UK. Journal of Corporate Finance, 7, 257-284.

Grossman, S. J. \& Hart, O. D. (1983). An analysis of the principal-agent problem. Econometrica: Journal of the Econometric Society, 7-45.

Guariglia, A., Liu, X. \& Song, L. (2011). Internal finance and growth: microeconometric evidence on Chinese firms. Journal of Development Economics, 96, 79-94.

Le, LH., De Ceuster Marc J.K, Plasmans Joseph, Le, TN., HA, MT. (2016). Do Vietnamese state-dominated listed firms face finance constraints. Journal of Science Ho Chi Minh City Open University, 18, 76-88.

Harris, J. R., Schiantarelli, F. \& Siregar, M. G. (1994). The effect of financial liberalization on the capital structure and investment decisions of Indonesian manufacturing establishments. The World Bank Economic Review, 8, 17-47.

Hayashi, F. (1982). Tobin's marginal q and average q: A neoclassical interpretation. Econometrica: Journal of the Econometric Society, 213-224.

Himmelberg, C. P. \& Petersen, B. C. (1994). R \& D and internal finance: A panel study of small firms in high-tech industries. The Review of Economics and Statistics, 76, 38-51.

Hubbard, R. G. (1998). Capital-market imperfections and investment. Journal of Economic Literature, 36, $193-225$. 
Hutchinson, J. \& Xavier, A. (2006). Comparing the impact of credit constraints on the growth of SMEs in a transition country with an established market economy. Small Business Economics, 27, 169-179.

Jensen, M. C. \& Meckling, W. H. (1976). Theory of the firm: Managerial behavior, agency costs and ownership structure. Journal of Financial Economics, 3, 305-360.

Kadapakkam, P. R., Kumar, P. \& Riddick, L. A. (1998). The impact of cash flows and firm size on investment: the international evidence. Journal of Banking and Finance, 22, 293-320.

Lizal, L. \& Svejnar, J. (2002). Investment, credit rationing, and the soft budget constraint: Evidence from Czech panel data. Review of Economics and Statistics, 84, 353-370.

Malesky, E. J. \& Taussig, M. (2009). Where Is Credit Due? Legal Institutions, Connections, and the Efficiency of Bank Lending in Vietnam. Journal of Law, Economics, and Organization, 25, 535.

Nguyen, H. T. \& Meyer, K. E. (2004). Managing Partnerships with State-Owned Joint Venture Companies: Experiences from Vietnam. Business Strategy Review, 15, 39-50.

Nguyen, T. A. (2006). Fiscal risks from the perspective of state-owned enterprises in Vietnam. Paper under sponsorship of Ministry of Finance of Vietnam presented in APEC Finance Ministers' Meeting, Hanoi 2006.

Nguyen, T. T. \& Van Dijk, M. A. (2012). Corruption, growth, and governance: Private vs. state-owned firms in Vietnam. Journal of Banking and Finance, 36, 2935-2948.

Perotti, E. C. \& Vesnaver, L. (2004). Enterprise finance and investment in listed Hungarian firms. Journal of Comparative Economics, 32, 73-87.

Plasmans, J. (2006). Modern linear and nonlinear econometrics, Springer Verlag.

Poncet, S., Steingress, W. \& Vandenbussche, H. (2010). Financial constraints in China: firm-level evidence. China Economic Review, 21, 411-422.

Scellato, G. (2007). Patents, firm size and financial constraints: an empirical analysis for a panel of Italian manufacturing firms. Cambridge Journal of Economics, 31, 55-76.

Schaller, H. (1993). Asymmetric information, liquidity constraints, and Canadian investment. Canadian Journal of Economics, 26, 552-574.

Sen, K., Vaidya, R. R. \& Sen, V. (1998). The process of financial liberalization in India, Oxford University Press, USA.

Shirai, S. (2004). Testing the three roles of equity markets in developing countries: the case of China. World Development, 32, 1467-1486.

State Bank of Vietnam (SBV) (2011). The System of Financial Institutions. http://www.sbv.gov.vn/.

Summers, L. H. (1981). Inflation, taxation, and corporate investment: a q-theory approach. NBER working paper No. 604.

Tobin, J. (1969). A general equilibrium approach to monetary theory. Journal of Money, Credit and Banking, 1 , $15-29$. 